\section{A conserved role for COMA/CENP-H/I/N kinetochore proteins in the spindle checkpoint}

\author{
Daniel R. Matson, ${ }^{1}$ Pinar B. Demirel, ${ }^{1}$ \\ P. Todd Stukenberg, and Daniel J. Burke ${ }^{2}$
}

Department of Biochemistry and Molecular Genetics, University of Virginia School of Medicine, Charlottesville Virginia, 22908, USA

\begin{abstract}
The COMA/CENP-H/I kinetochore complex regulates microtubule dynamics at kinetochores. The complex is also required to generate spindle checkpoint signals in both yeast and human cells under conditions where Aurora B activity is compromised. Our data explain why mammalian cells treated with Aurora inhibitors still have a functional spindle assembly checkpoint (SAC), since the checkpoint signals through CENP-H/I/N. The SAC effect from depleting the CENP-H/I/N complex cannot be explained by a weakened SAC signal, and the complex has no role in the SAC response to paclitaxel. We propose a model to explain the differential response of human cells to nocodazole and paclitaxel.
\end{abstract}

Supplemental material is available for this article.

Received November 27, 2011; revised version accepted February 17, 2012.

Improperly attached kinetochores prevent anaphase onset by generating a signal though the spindle assembly checkpoint (SAC) (Nezi and Musacchio 2009). Robust SAC signals can be generated by a single kinetochore that recruits the SAC proteins Mps1, Mad1, Mad2, BubR1, Bub1, and Bub3, which are modified to generate a signal that can inhibit mitotic progression (Musacchio and Salmon 2007). The KMN complex, composed of Knll, Mis12, and the Ndc80 kinetochore complex proteins, binds microtubules and is required to recruit SAC proteins to unattached kinetochores (McCleland et al. 2003; Kiyomitsu et al. 2007). It remains unclear how kinetochores coordinate SAC protein recruitment with microtubule attachments to regulate the signal.

The 17-protein constitutive centromere-associated network (CCAN) has multiple functions in kinetochores (Foltz et al. 2006). It recruits CENP-A to centromeres, anchors kinetochores to centromeric nucleosomes, and has a role in chromosome congression (Liu et al. 2003, Carroll et al. 2009, 2010; Gascoigne et al. 2011; Screpanti et al. 2011). Most of the CCAN proteins are conserved in budding yeast, where they are members of the COMA

\footnotetext{
[Keywords: spindle assembly checkpoint; kinetochore; mitosis]

${ }^{1}$ These authors contributed equally to this work.

${ }^{2}$ Corresponding author.

E-mail dburke@virginia.edu.

Article is online at http://www.genesdev.org/cgi/doi/10.1101/gad.184184.111.
}

and COMA-associated complexes (De Wulf et al. 2003; Westermann et al. 2003; Meraldi et al. 2006). The CENP$\mathrm{H} / \mathrm{I}$ complex is a subassembly of CCAN that includes the CENP-H/I/K proteins and is required to recruit the CENP$\mathrm{O} / \mathrm{P} / \mathrm{Q}$ proteins to kinetochores. The CENP-H/I complex regulates the dynamics of microtubules that are embedded in kinetochores, and CENP-N contacts the CENP-A nucleosome. (Carroll et al. 2009; Amaro et al. 2010)

The SAC signal is generated by kinetochores that lack embedded microtubules or by kinetochores that are not physically separated by pulling forces from the mitotic spindle (Nezi and Musacchio 2009). The latter may be indirect because the Aurora kinases can release kinetochore-bound microtubules (Biggins et al. 2001; Tanaka et al. 2002). Paclitaxel treatment allows kinetochores of human cells to bind microtubules but causes cells to arrest in mitosis in an Aurora B-dependent manner (Ditchfield et al. 2003; Hauf et al. 2003). In contrast, cells lacking Aurora B activity arrest in the presence of microtubuledepolymerizing drugs (Ditchfield et al. 2003; Hauf et al. 2003). Yeast cells lacking cohesion between sister chromatids arrest in mitosis. However, cells lacking cohesion cannot arrest if the Aurora kinase Ipll is unable to phosphorylate Mad3, but are able to arrest when microtubules are completely depolymerized (King et al. 2007). In this study, we build on Aurora-dependent and Auroraindependent checkpoint signaling responses in yeast to identify novel SAC proteins. We show that yeast require Chl4, Ctf3, and Ctf19, members of the COMA-associated kinetochore complex (COMA), to arrest in response to microtubule depolymerization when Mad3 is unphosphorylated by Ipll. This novel SAC response is evolutionarily conserved. Human cells lacking COMA homologs CENP-H, CENP-I, or CENP-N (hereafter referred to as $\mathrm{CENP}-\mathrm{H} / \mathrm{I} / \mathrm{N}$ ) arrest in paclitaxel but require full activity of Aurora kinase to arrest in response to microtubule depolymerization by nocodazole. CENP-H/I/N is required to recruit the Mad2 SAC protein to prometaphase kinetochores. We found no role for the CENP-H/I/N in paclitaxel, arguing that the CENP-H/I/N pathway is extinguished upon microtubule binding. We confirmed that Aurora has a SAC role independent of releasing microtubules and propose that the spindle checkpoint has independent branches that converge on cell cycle regulation.

\section{Results and Discussion}

Budding yeast depleted of Cdc6 enter mitosis in the absence of DNA replication and arrest cell cycle progression by triggering the SAC (Stern and Murray 2001). Ipl1 must phosphorylate Mad3 on S337 to generate a SACdependent arrest in response to the loss of sister chromatid cohesion (King et al. 2007). mad3-S337A cells (hereafter referred to as $\operatorname{mad}^{\star}$ ) are unable to arrest as large-budded cells (mitotic) in response to Cdc6 depletion but are able to arrest in response to benomyl, which depolymerizes microtubules (Fig. 1A). This is in contrast to the previous study that required an additional mutation in mad3 for the similar phenotype for reasons that are probably attributable to strain differences (King et al. 2007). The ability to arrest when microtubules were missing but not after Cdc6 depletion suggested that there was an additional component of the SAC in mad3* cells mediating the microtubule- 


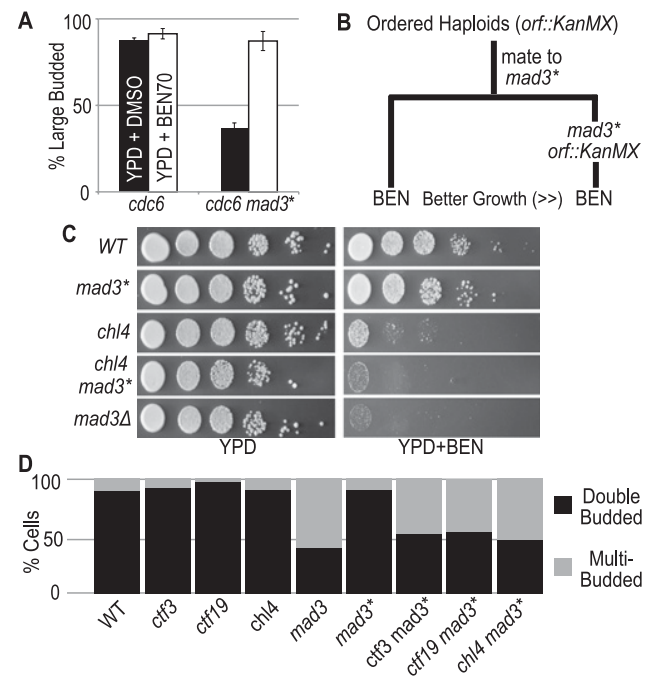

Figure 1. SGA analysis identified the COMA complex as integral to the occupancy checkpoint. $(A)$ Rebudding assay. Cells were plated on YPD and YPD + Ben $(70 \mu \mathrm{g} / \mathrm{mL})$ to deplete Cdc6, followed by time-lapse photography. Mitotic cells are double-budded after $9 \mathrm{~h}$ at $30^{\circ} \mathrm{C}$. (B) SGA analysis. Single mutants orf::KanMX (left side) and double mutants (right side) plated onto YPD $+15 \mu \mathrm{g} / \mathrm{mL}$ benomyl. Interesting mutants show more growth $(>>)$ as single mutants. (C) Benomyl sensitivity. Tenfold dilutions from saturated cultures were spotted onto YPD + DMSO and YPD $+15 \mu \mathrm{g} / \mathrm{mL}$ benomyl for $4 \mathrm{~d}$ at $23^{\circ} \mathrm{C}$. $(D)$ Time-lapse photography of cells as in $A$ grown on glucose + Ben $(70 \mu \mathrm{g} / \mathrm{mL})$.

dependent arrest. To identify this SAC activity, we performed a genome-wide screen using synthetic genetic array (SGA) technology to construct all possible double mutants with the haploid deletion collection (Tong et al. 2001). We compared the benomyl sensitivity of haploids from the deletion collection to double mutants. We were interested in any mutants where growth in the presence of a sublethal concentration of benomyl was reduced in the double mutant (Fig. 1B). chl4 was benomyl-sensitive as a single mutant but had enhanced sensitivity in the double mutant, similar to mad3s (Fig. 1C). The chl4 and mad3* cells arrested as large-budded cells, but the double-mutant cells did not and behaved like mad3s cells (Fig. 1D). Chl4 is a member of a three-protein subcomplex of the kinetochore (along with Ctf3 and Ctf19) that is part of the larger COMA complex. All three proteins are required for SAC activity, as judged by their requirement to arrest as doublebudded cells during growth in benomyl (Fig. 1D). To confirm the requirement for SAC activity, we analyzed the single and double mutants by synchronous growth. Cells were released from $\alpha$-factor arrest, followed through mitosis by measuring the degradation of Pds1 and DNA content by flow cytometry. Wild-type, chl4, and mad3* cells arrested when microtubules were depolymerized by benomyl as Pds1 levels were stabilized (Fig. 2 A-C) and the cells arrested with replicated DNA (Fig. 2I). In contrast, chl4 mad3* cells did not maintain stable Pds1 or replicated DNA (Fig. 2 F,I). ctf3 and ctf19 cells behaved similarly (Fig. 2D,E; Supplemental Fig. 1) and arrested in response to benomyl. The $c t f 3$ mad3* and ctf19 mad3* cells were unable to maintain a mitotic arrest (Fig. 2 G,H; Supplemental Fig. 1). Therefore, by three independent measurements (budding morphology, flow cytometry, and Pds1 stability), we identified Ctf3, Chl4, and Ctf19 as part of a SAC pathway that is required to arrest cells lacking microtubules.
We analyzed COMA homologs in human cells to determine whether they have a conserved role in the SAC. We used siRNA conditions that depleted the CENP proteins but did not appreciably affect CENP-A levels. We confirmed an increase in mitotic index after siRNAmediated depletion of CENP-H, CENP-I, or CENP-N in HeLa cells after $48 \mathrm{~h}$ that had previously been attributed to defects in chromosome segregation (Liu et al. 2003; Amaro et al. 2010). The arrest required Aurora B activity, as 1-h treatment with the Aurora B inhibitor ZM447439 induced mitotic exit and reduced the mitotic index (Fig. 3A). Inhibiting Aurora B causes paclitaxel-arrested cells to exit mitosis after $1 \mathrm{~h}$, while nocodazole-arrested cells remain in mitosis for $6 \mathrm{~h}$ (Ditchfield et al. 2003; Hauf et al. 2003). HeLa cells were treated with siRNA against CENP-I or LacZ for $32 \mathrm{~h}$ and incubated with $3.3 \mu \mathrm{M}$ nocodazole for an additional $16 \mathrm{~h}$ with either the inhibitor ZM447439 (Ditchfield et al. 2003; Hauf et al. 2003) or DMSO added for the final hour. LacZ cells treated with ZM447439 remained arrested in nocodazole, while CENP-I-depleted cells exited mitosis (Fig. 3B). Increasing the concentration of ZM447439 caused an increase in the number of CENP-I-depleted cells that exited mitosis but had little effect on control cells (Fig. 3C). Similar results were obtained with the Aurora B inhibitor Hesperadin, whose structure is unrelated to ZM447439 (Fig. 4A). In addition, A549, U2OS, and 293T cells in nocodazole also exited mitosis after CENP-I depletion and ZM447439 treatment (Supplemental Fig. 2). The phenotype was due to CENP-I depletion, as it was partially rescued with a plasmid containing CENP-I cDNA (Supplemental Fig. 3). CENP-H and CENP-N are also required for this Aurora B-independent pathway of the SAC (Supplemental Fig. 4A). Our siRNAs did not have off-target effects on the SAC protein Mad2 (Hubner et al. 2010; Westhorpe et al. 2010) because the intracellular Mad2 levels remained constant after siRNA treatment (Supple-

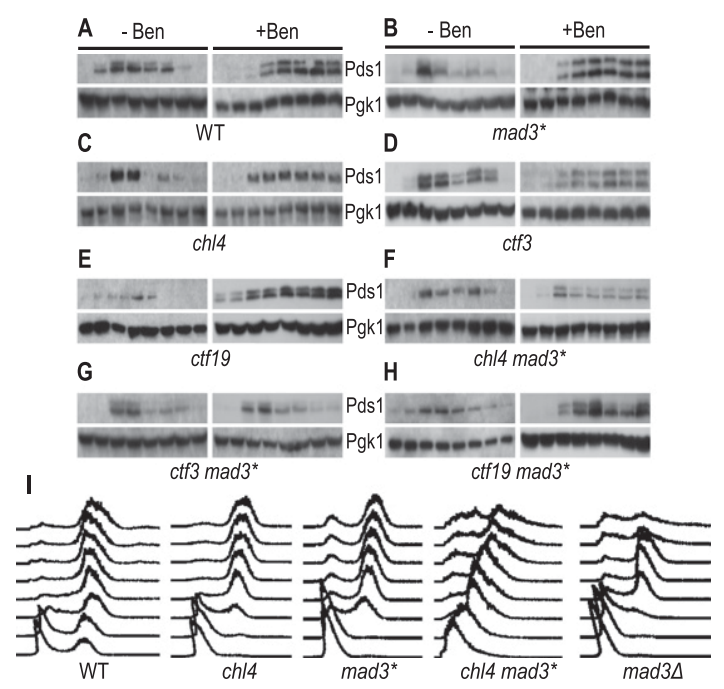

Figure 2. CTF3 is required for SAC activity. $\alpha$-Factor-arrested cells of the indicated genotypes were released into the cell cycle in the presence or absence of microtubules. Samples were taken every 20 min for immunoblot and flow cytometry analysis. Protein extracts were separated by SDS-PAGE and immunoblotted with mouse monoclonal anti-HA (12CA5) and anti-PGK1 antibodies to identify Pds1 and Pgk1. 

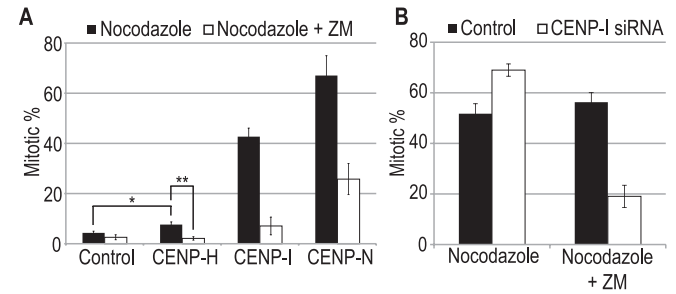

C
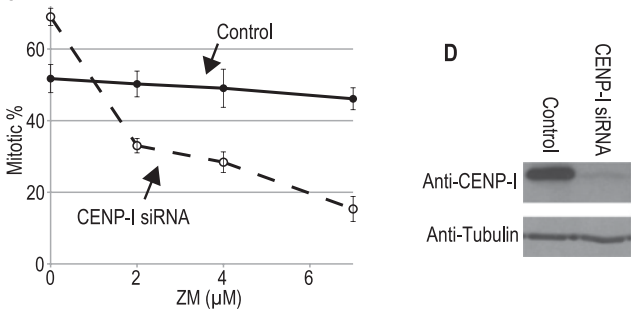

Figure 3. Depletion of CENP-I impairs the ability of ZM447439treated HeLa cells to arrest in nocodazole. $(A)$ HeLa cells depleted of CENP-H, CENP-I, or CENP-N increased the basal mitotic index in a manner sensitive to Aurora kinase inhibition. Western blots of depletion are shown in Supplemental Figure 5. Even a modest depletion of CENP-H resulted in a significant increase in mitotic index that was susceptible to Aurora kinase inhibition. $\left({ }^{*}\right) 0.02 ;\left(^{* *}\right)$ 0.005. (B) CENP-I siRNA-treated HeLa cells exit mitosis in the presence of nocodazole after 1-h treatment with ZM447439, while LacZ control cells remain arrested. $(C)$ CENP-I-depleted HeLa cells treated with nocodazole exit mitosis in response to ZM447439 in a dose-dependent manner. $(D)$ Western blots of HeLa whole-cell lysate demonstrating degree of CENP-I depletion.

mental Fig. 5A). We looked at the status of the kinetochore after CENP-I depletion in the presence of nocodazole and found that Knl-1, p150 dynactin, ZW10, and Mps1 were kinetochore-associated (Supplemental Fig. 6). CENP-P levels were decreased, as previously published (Amaro et al. 2010). We conclude that the effect of CENP-I depletion on the SAC is not the indirect consequence of an effect on kinetochore assembly.

Our data are consistent with a recent report suggesting that Aurora kinase has a direct role in the SAC and does not simply release kinetochores from microtubules (Santaguida et al. 2010). We confirmed that no microtubules were visible in CENP-I-depleted cells cultured in $3.3 \mu \mathrm{M}$ nocodazole and ZM447439 (Fig. 4B), ruling out the possibility that the checkpoint was satisfied after Aurora B inhibition because microtubules become attached to kinetochores. Additionally, Aurora B remained at centromeres in cells treated with nocodazole and ZM447439, ruling out the possibility that the kinase was mislocalized due to drug treatment (Supplemental Fig. 7).

One interpretation is that cells generate two independent SAC signals, one requiring Aurora B and another requiring CENP-H/I/N. However, it is possible that Aurora $B$ and CENP-H/I/N contribute to the same pathway that can weakly signal but is more deficient when both proteins are missing. Partial inhibition of Mps1 causes a weakened SAC signal (Santaguida et al. 2010). We titrated paclitaxel into cells with the partially inhibited Mps 1 and found that they required a higher concentration of paclitaxel to arrest (Supplemental Fig. 8). We used paclitaxel titration to determine whether CENP-H/I/N depletion weakened the SAC signal. Although CENP-I depletion results in an increased basal mitotic index, the effective concen- tration of paclitaxel is similar to LacZ control (Fig. 4C). Cells depleted of CENP-H, CENP-Q, and CENP-N also arrested at very similar paclitaxel concentrations (Supplemental Fig. 4B). We saw no role for CENP-H/I/N in the paclitaxel arrest, arguing that the signal is shut off after microtubule attachment. To determine whether CENP-H/I/N has a role in prolonged arrest by paclitaxel, we time-lapse-imaged control and CENP-I-depleted cells for $20 \mathrm{~h}$ at saturating levels of paclitaxel to detect subtle differences in the strength of the mitotic arrest. The proportion of cells that remained arrested for the duration of the experiment was similar /control 33\% vs. CENP-I $37 \%$ ). In addition, the distribution of times at which cells apoptosed was not significantly different $(P=0.23)$ (Supplemental Fig. 9). Thus, by two independent assays, cells depleted of CENP-I have a robust arrest in paclitaxel that is not compromised. Our results from yeast and human cells are most consistent with two distinct pathways, both of which are capable of independently generating a robust SAC signal.

Cells in prometaphase recruit both Mad2 and BubR1 to kinetochores, which correlates strongly with SAC signaling (Taylor et al. 1998; Waters et al. 1998). We determined whether CENP-H/I/N-depleted cells in prometaphase recruit SAC proteins. We performed quantitative immunofluorescence (IF) of several kinetochore and centromere proteins after CENP-I depletion (Fig. 5A,B; Supplemental Fig. 6). We could detect mild decreases in CENP-A and Hec 1 following CENP-I depletion. These observations are consistent with earlier observations demonstrating a subtle requirement for CENP-I in CENP-A loading and Hec1 recruitment (Cheeseman et al. 2008; Amaro et al. 2010). This slight reduction of Hecl following CENP-I depletion cannot explain the loss of SAC signal because it takes

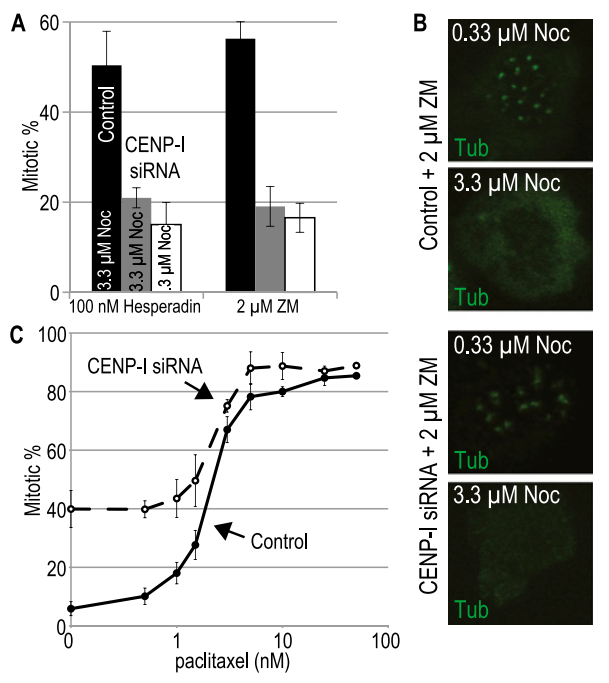

Figure 4. CENP-I-depleted HeLa cells are sensitive to Aurora B inhibition in the presence of nocodazole but arrest similarly to control cells at low doses of paclitaxel. (A) CENP-I-depleted HeLa cells treated with either Hesperadin or ZM447439 at concentrations that inhibit $50 \%$ of Aurora B activity produce similar reductions in mitotic index. Similar numbers of cells arrested in either $3.3 \mu \mathrm{M}$ or $0.33 \mu \mathrm{M}$ nocodazole. (B) Anti-tubulin IF of LacZ or CENP-I siRNAtreated HeLa cells following treatment with $0.33 \mu \mathrm{M}$ or $3.3 \mu \mathrm{M}$ nocodazole, demonstrating that $3.3 \mu \mathrm{M}$ nocodazole is required to completely depolymerize cellular tubulin. (C) CENP-I-depleted HeLa cells arrest at concentrations of paclitaxel similar to controls. 


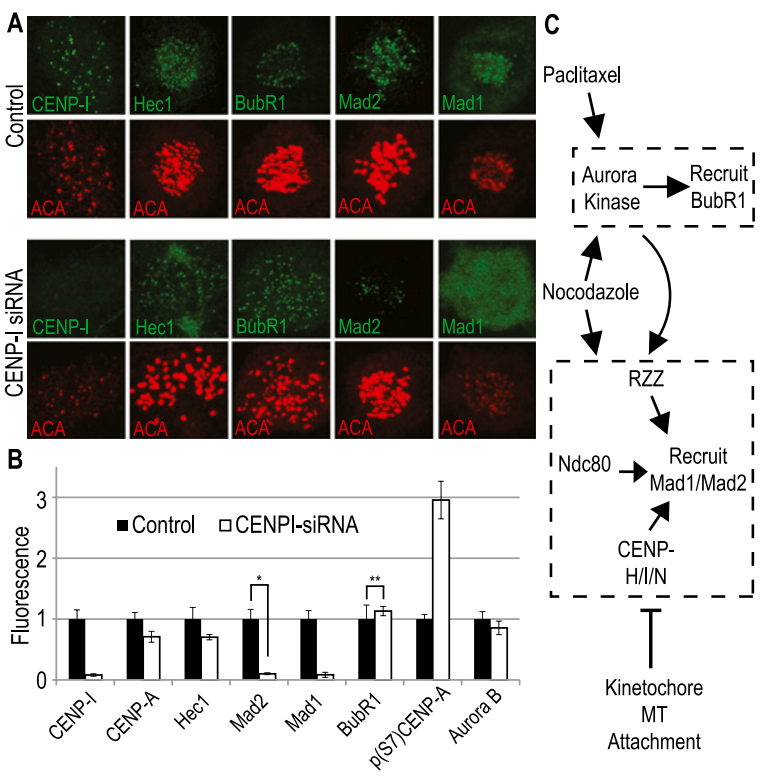

Figure 5. CENP-I depletion alters the levels of checkpoint components and stimulates Aurora kinase activity at the kinetochore. $(A)$ CENP-I-depleted HeLa cells can localize components of the outer kinetochore, as well as the critical checkpoint proteins BubR1 and reduced levels of Mad1 and Mad2. (B) Quantitative IF demonstrating that depletion of CENP-I causes slightly decreased levels of CENP-A and $\mathrm{Hecl}$ at kinetochores, while Mad1 and Mad2 levels at kinetochores are significantly reduced. Interestingly, although BubR1 and Aurora B levels at kinetochores are unchanged, levels of the Aurora B substrate $\mathrm{p}(\mathrm{S} 7)$ CENP-A are significantly elevated. $\left({ }^{\star}\right) P=0.0031$; $\left.{ }^{\star \star \star}\right) P=0.61$. $(C)$ Model of pathways stimulated by paclitaxel and nocodazole. See the text for details.

$>97 \%$ depletion of Ndc80 complex activity to abrogate the SAC signal (Meraldi et al. 2004). In contrast, the levels of Mad2 were significantly reduced to $10 \%$ of wild-type levels $(P=0.003)$, and Mad1, which recruits Mad2 to prometaphase kinetochores, was also reduced (Fig. 5), in agreement with a previous report (Liu et al. 2003). BubR1 was present at prometaphase kinetochores after CENP-I depletion at levels not different from control cells (Fig. 5A,B). The levels of the Aurora B substrate p(S7)CENP-A were increased almost $300 \%$ in CENP-I-depleted cells over controls, even though the amount of substrate was slightly reduced. We did not detect a significant difference in Aurora B levels at these kinetochores, indicating that net Aurora B activity is increased at the kinetochores of CENP-I-depleted cells, consistent with our observation that CENP-I-depleted cells arrest in an Aurora B-dependent manner.

We demonstrated that a subset of kinetochore proteins from the COMA-associated complex in yeast and their homologs, CENP-H/I/N in humans, play a role in both recruiting Mad2 to prometaphase kinetochores and generating the SAC signal. The role of CENP-H/I/N is unique among SAC proteins and is only uncovered when Aurora kinase activity is compromised. We found no role for CENP-H/I/N in a paclitaxel arrest that is dependent on high amounts of Aurora B activity (Ditchfield et al. 2003; Hauf et al. 2003). Previous studies have struggled with the role of Aurora kinase in the SAC, in part because the enzyme can activate the checkpoint indirectly by generating unattached kinetochores, making it difficult to assign a direct signaling role to the kinase (Pinsky et al. 2006;
Santaguida et al. 2011). Our data support a direct role for Aurora B in checkpoint signaling in cells treated with nocodazole (Santaguida et al. 2011; Saurin et al. 2011). Furthermore, they are the first to explain why cells lacking Aurora B activity in nocodazole can still arrest (Ditchfield et al. 2003; Hauf et al. 2003), since they are still able to generate a signal through the CENP-H/I/N complex. Mad1 and $\mathrm{Mad} 2$ recruitment are codependent on three kinetochore complexes. Ndc80 and RZZ complexes are also required for Mad1 and Mad2 recruitment to kinetochores, and both complexes are at kinetochores depleted of CENP-I (Fig. 5; Supplemental Fig. 6; Liu et al. 2003).

We propose a model to explain the differential response of human cells to nocodazole and paclitaxel and the requirement of $\mathrm{CEN}-\mathrm{H} / \mathrm{I} / \mathrm{N}$ in the nocodazole response. Mad1/2 recruitment by the three kinetochore complexes RZZ, Ndc80, and CENP-H/I/N is antagonized by kinetochore microtubule attachment (Fig. 5C). Aurora B has at least two functions in SAC signaling: BubR1 and RZZ recruitment to kinetochores. The latter is also required to recruit Mad2. Paclitaxel only triggers the Aurora B recruitment of BubR1, and the entire RZZ, Ndc80, and CENP$\mathrm{H} / \mathrm{I} / \mathrm{N}$ branch is extinguished by microtubule attachment. Nocodazole triggers both branches of the SAC pathways. The paclitaxel response requires Mad1 and Mad2, which can be explained by either additional roles for the soluble pools of these proteins or occasional release of paclitaxelstabilized microtubules from kinetochores (Waters et al. 1998; Musacchio and Salmon 2007).

Since taxanes and vinca alkaloids are effective chemotherapeutics (Matson and Stukenberg 2011), the identification of any new proteins involved in spindle checkpoint signaling provides a promising new avenue for the development of anti-neoplastic therapies. Our findings also suggest that paclitaxel arrests cancer cells in a manner that depends solely on Aurora kinase activity, while microtubuledestabilizing agents like nocodazole also arrest cells through the CENP-H/I/N complex. It will be important to determine how this insight can be used to generate more efficacious combination chemotherapeutic strategies.

\section{Materials and methods}

\section{Yeast strains and media}

Yeast strains are listed in Supplemental Table 1. Ser 337 on Mad3 was mutated (mad3-S337A) with QuickChange (Stratagene) following the manufacturer's instructions. PDS1-3HA (pVG319 digested with KpnI) was integrated at PDS1. GAL-CDC6 was integrated using pG15 (PstI), and transformants were selected on $1 \%$ galactose $+2 \%$ raffinose containing SC-Trp. Transformations were as described (Gietz and Schiestl 2007). YM-1, YPD, and SC media were prepared as described (Amberg et al. 2005).

\section{Benomyl sensitivity assay}

Cells were grown to saturation in YM-1, and $5 \mu \mathrm{L}$ of the 10 -fold serially diluted aliquots were spotted and incubated for $4 \mathrm{~d}$ at $23^{\circ} \mathrm{C}$.

\section{Yeast cell cycle experiments}

Cells in YM-1 or SC-Leu (OD $=\sim 0.4$ ) were synchronized in G1 with 1:200 dilution of a $10 \mathrm{mM} \alpha$-factor stock solution in acidic YM-1 + Glu (pH 3.41) as described previously (Yellman and Burke 2004). Arrested cells were washed three times with water and released into YM-1 medium in the presence or absence of microtubule-depolymerizing drugs. Nocodazole $(15 \mu \mathrm{g} / \mathrm{mL})$ was used to induce microtubule depolymerization. Some experiments were with a mixture of $25 \mu \mathrm{g} / \mathrm{mL}$ carbendezim (Sigma) $+10 \mu \mathrm{g} / \mathrm{mL}$ 
benomyl, and either treatment is labeled "Ben." Samples were collected for immunoblots and FACScan every 20 min. Protein extracts were prepared as described previously (Kushnirov 2000). Immunoblots were for mouse monoclonal 12CA5 and anti-PGK1 (Yellman and Burke 2004). Samples were fixed with $70 \%$ ethanol and prepared for flow cytometry as described previously (Yellman and Burke 2004). The DNA content of 40,000 cells was determined for each sample.

\section{Yeast rebudding assay}

Cells were spread onto agar Petri plates containing YPD and YPD in $70 \mu \mathrm{g} / \mathrm{mL}$ benomyl in $1 \%$ DMSO, and pictures of random fields were taken $\left(\mathrm{t}_{0}\right)$. The same fields were photographed after 6 and $9 \mathrm{~h}$, and the unbudded cells $\left(\mathrm{t}_{0}\right)$ were categorized into double-budded or multibudded phenotypes.

\section{Genetic screen}

The plasmid-borne mad3-S337A allele (marked by LEU2) was crossed into the haploid deletion collection, and double mutants were obtained in a manner analogous to that described previously (Tong et al. 2001). Diploids were selected and sporulated, and haploids were selected as described (Tong et al. 2001). The haploid deletion library and the haploid double mutants were individually replica-plated onto agar medium containing YPD $15 \mu \mathrm{g} / \mathrm{mL}$ benomyl and compared after $4 \mathrm{~d}$.

\section{Cell culture, siRNA, and drug treatments}

HeLa cells were cultured in Dulbecco's modified Eagle medium (DMEM) and plated at $25 \%$ confluency into 12 -well plates the evening prior to siRNA transfection. Transfection of siRNA was carried out using RNAiMAX (Invitrogen) as described by the manufacturer. CENP siRNAs (Dharmacon) were used at $20 \mathrm{nM}$ (sequences in Supplemental Table 2). LacZ siRNA was the control. A different siRNA against the CENP-I untranslated region was used in the rescue experiment (Qiagen) at 50 $\mathrm{nM}$. Nocodazole was used at $3.3 \mu \mathrm{M}$, paclitaxel was used at $1 \mu \mathrm{M}$, and treatment periods were $16 \mathrm{~h}$ unless noted otherwise. ZM447439 (Tocris) was used at $2 \mu \mathrm{M}$ unless otherwise stated, and Hesperadin (Boehringer Ingelheim) was used at $100 \mathrm{nM}$.

\section{IF, antibodies, and mitotic index assays}

IF experiments were performed on cells that were fixed with $2 \%$ paraformaldehyde for 20 min without previous extraction and were processed as previously described (Bolton et al. 2002). Antibodies were as follows: CENP-A (Abcam), Hec1 (9G3, GeneTex), Mad2 (for IF; G. Gorbsky), Mad2 (for Western blots; Bethyl Laboratories), CENP-Q (A. McAinsh), CENP-P (A. McAinsh), ZW10 (Abnova), Mps1 (Millipore), Knl1 (I. Cheeseman), BubR1 (Miller et al. 2008), p(S7)CENP-A (Cell Signaling), and Madl (P. Meraldi). CENP-I and CENP-H polyclonal rabbit antibodies were generated and affinity-purified with recombinant full-length proteins as previously described (Bolton et al. 2002). Western blots of HeLa whole-cell lysates are shown in Supplemental Figure 6. Imaging was performed on a Zeiss Axiovert 200 microscope with PerkinElmer-RS spinning disk confocal system illuminated by a krypton/argon laser. Digital images were obtained with a Hamamatsu EMCCD camera. Image acquisition was performed using Volocity software (PerkinElmer), and images were analyzed using ImageJ (NIH). For quantitative IF, a circular region encompassing one kinetochore was measured, and gray level intensity was measured for both the experimental antibody and ACA, as well as background in both channels, in both the control and depleted cells. Intensity was calculated by taking the intensity of the experimental antibody minus background and dividing it by the intensity of ACA staining minus background. At least 100 experimental and 100 control kinetochores were evaluated for CENP-I, Mad2, and CENP-A; 60 kinetochores were evaluated for Hecl and $\mathrm{p}$ (S7)CENP-A; and 50 kinetochores were evaluated for BubR1 and Mad1. Cells were treated with either target siRNA or LacZ siRNA, and the cells were incubated for $48 \mathrm{~h}$ to assay the SAC in HeLa cells. Cells were treated with $3.3 \mu \mathrm{M}$ nocodazole for the last $16 \mathrm{~h}$, and for the last 1 $\mathrm{h}$, they were treated with varying amounts of ZM447439 or a DMSO control. HeLa cells were trypsinized and fixed in $70 \%$ ethanol for $3 \mathrm{~h}$ at $-20^{\circ} \mathrm{C}$. The cells were then pelleted, resuspended in ice-cold $0.1 \%$ Triton X-100 in PBS for 15 min, washed, and stained for the metaphase marker p(T72)Inhibitor-2 (D. Brautigan) (Invitrogen) and DAPI according to standard protocols. Both the p(T72)Inhibitor-2 staining and morphology of DAPI-stained chromatin were then scored to determine mitotic index. Each treatment group was performed four times, with at least 200 nuclei scored in each experiment (for $n=4$ and $>800$ total cells scored per treatment).

\section{CENP-I rescue experiments}

pCS2-CENP-I was constructed using restriction sites Clal and Xhol. HeLa cells were plated at $30 \%$ and the next morning were transfected with $50 \mathrm{nM}$ siRNA against CENP-I UTR. Medium was changed after $6 \mathrm{~h}$. The cells were transfected with either pCS2-CENP-I or pCS2 ${ }^{+}$control plasmid after a 24-h incubation, the medium was changed after $6 \mathrm{~h}$, and the cells were allowed to incubate for $48 \mathrm{~h}$ post-transfection. For the last $16 \mathrm{~h}$, the cells were treated with $3.3 \mu \mathrm{M}$ nocodazole. ZM447439 $(2 \mu \mathrm{M})$ was added to one group for the last hour. The cells were then trypsinized and assayed for mitotic index.

\section{Cell fate experiments}

HeLa cells were seeded into \#1.5 borosilicate chamber slides and treated with $20 \mathrm{nM}$ CENP-I siRNA or Lipofectamine control the following morning. After $6 \mathrm{~h}$, the medium was replaced with DMEM/10\%FBS and $15 \mathrm{mM}$ HEPES (pH 7.4). Cells were incubated for $36 \mathrm{~h}$ and then placed in 1 $\mu \mathrm{M}$ paclitaxel. The cells were then imaged for $20 \mathrm{~h}$ on a DeltaVision microscope (Applied Precision) (Barnhart et al. 2011) using a 40× objective, with bright-field images captured every $10 \mathrm{~min}$. Duration of mitoses and cell fates were scored by analyzing the resulting movies. Cells that remained after imaging were fixed for IF against CENP-I as previously described (Bolton et al. 2002) to assess the degree of depletion.

\section{Statistical methods}

For statistical analysis, mean values with standard deviation (SD) are shown in most graphs that were generated from several independently obtained data sets. $P$-values were obtained from $t$-tests with paired or unpaired samples.

\section{Acknowledgments}

We thank Gary Gorbsky, Patrick Meraldi, Andrew McAinsh, Tim Yen, Iain Cheeseman, John Diffley, and Vincent Guacci for reagents. This work was funded by grants GM063045 and GM081576 to P.T.S. and GM086502 to D.J.B. D.R.M. is funded by NIH training grants T32GM007267 and T32GM008136. P.B.D. and D.J.B. designed and executed the yeast experiments. D.R.M. and P.T.S. designed and executed the tissue culture experiments.

\section{References}

Amaro AC, Samora CP, Holtackers R, Wang E, Kingston IJ, Alonso M, Lampson M, McAinsh AD, Meraldi P. 2010. Molecular control of kinetochore-microtubule dynamics and chromosome oscillations. Nat Cell Biol 12: 319-329.

Amberg DC, Burke D, Strathern J. 2005. Methods in yeast genetics. Cold Spring Harbor Laboratory Press, Cold Spring Harbor, NY.

Barnhart MC, Kuich PH, Stellfox ME, Ward JA, Bassett EA, Black BE, Foltz DR. 2011. HJURP is a CENP-A chromatin assembly factor sufficient to form a functional de novo kinetochore. J Cell Biol 194: 229-243.

Biggins S, Bhalla N, Chang A, Smith DL, Murray AW. 2001. Genes involved in sister chromatid separation and segregation in the budding yeast Saccharomyces cerevisiae. Genetics 159: 453-470.

Bolton M, Lan W, Powers S, McCleland M, Kuang J, Stukenberg P. 2002. Aurora B kinase exists in a complex with Survivin and INCENP and its kinase activity is stimulated by Survivin binding and phosphorylation. Mol Biol Cell 13: 3064-3077.

Carroll CW, Silva MC, Godek KM, Jansen LE, Straight AF. 2009. Centromere assembly requires the direct recognition of CENP-A nucleosomes by CENP-N. Nat Cell Biol 11: 896-902. 
Carroll CW, Milks KJ, Straight AF. 2010. Dual recognition of CENP-A nucleosomes is required for centromere assembly. J Cell Biol 189: 1143-1155.

Cheeseman IM, Hori T, Fukagawa T, Desai A. 2008. KNL1 and the CENP-H/I/K complex coordinately direct kinetochore assembly in vertebrates. Mol Biol Cell 19: 587-594.

De Wulf P, McAinsh AD, Sorger PK. 2003. Hierarchical assembly of the budding yeast kinetochore from multiple subcomplexes. Genes Dev 17: 2902-2921.

Ditchfield C, Johnson VL, Tighe A, Ellston R, Haworth C, Johnson T, Mortlock A, Keen N, Taylor SS. 2003. Aurora B couples chromosome alignment with anaphase by targeting BubR1, Mad2, and Cenp-E to kinetochores. J Cell Biol 161: 267-280.

Foltz DR, Jansen LE, Black BE, Bailey AO, Yates JR 3rd, Cleveland DW. 2006. The human CENP-A centromeric nucleosome-associated complex. Nat Cell Biol 8: 458-469.

Gascoigne KE, Takeuchi K, Suzuki A, Hori T, Fukagawa T, Cheeseman IM. 2011. Induced ectopic kinetochore assembly bypasses the requirement for CENP-A nucleosomes. Cell 145: 410-422.

Gietz RD, Schiestl RH. 2007. High-efficiency yeast transformation using the LiAc/SS carrier DNA/PEG method. Nat Protoc 2: 31-34.

Hauf S, Cole RW, LaTerra S, Zimmer C, Schnapp G, Walter R, Heckel A, van Meel J, Rieder CL, Peters JM. 2003. The small molecule Hesperadin reveals a role for Aurora B in correcting kinetochoremicrotubule attachment and in maintaining the spindle assembly checkpoint. J Cell Biol 161: 281-294.

Hubner NC, Wang LH, Kaulich M, Descombes P, Poser I, Nigg EA. 2010. Re-examination of siRNA specificity questions role of PICH and Taol in the spindle checkpoint and identifies Mad2 as a sensitive target for small RNAs. Chromosoma 119: 149-165.

King EM, Rachidi N, Morrice N, Hardwick KG, Stark MJ. 2007. Ipllpdependent phosphorylation of Mad3p is required for the spindle checkpoint response to lack of tension at kinetochores. Genes Dev 21: 1163-1168.

Kiyomitsu T, Obuse C, Yanagida M. 2007. Human Blinkin/AF15q14 is required for chromosome alignment and the mitotic checkpoint through direct interaction with Bub1 and BubR1. Dev Cell 13: 663676.

Kushnirov VV. 2000. Rapid and reliable protein extraction from yeast. Yeast 16: 857-860.

Liu ST, Hittle JC, Jablonski SA, Campbell MS, Yoda K, Yen TJ. 2003. Human CENP-I specifies localization of CENP-F, MAD1 and MAD2 to kinetochores and is essential for mitosis. Nat Cell Biol 5: 341-345.

Matson DR, Stukenberg PT. 2011. Spindle poisons and cell fate: A tale of two pathways. Mol Interv 11: 141-150.

McCleland ML, Gardner RD, Kallio MJ, Daum JR, Gorbsky GJ, Burke DI, Stukenberg PT. 2003. The highly conserved Ndc80 complex is required for kinetochore assembly, chromosome congression, and spindle checkpoint activity. Genes Dev 17: 101-114.

Meraldi P, Draviam VM, Sorger PK. 2004. Timing and checkpoints in the regulation of mitotic progression. Dev Cell 7: 45-60.

Meraldi P, McAinsh AD, Rheinbay E, Sorger PK. 2006. Phylogenetic and structural analysis of centromeric DNA and kinetochore proteins. Genome Biol 7: R23. doi: 10.1186/gb-2006-7-3-r23.

Miller SA, Johnson ML, Stukenberg PT. 2008. Kinetochore attachments require an interaction between unstructured tails on microtubules and Ndc80(Hec1). Curr Biol 18: 1785-1791.

Musacchio A, Salmon ED. 2007. The spindle-assembly checkpoint in space and time. Nat Rev Mol Cell Biol 8: 379-393.

Nezi L, Musacchio A. 2009. Sister chromatid tension and the spindle assembly checkpoint. Curr Opin Cell Biol 21: 785-795.

Pinsky BA, Kung C, Shokat KM, Biggins S. 2006. The Ipl1-Aurora protein kinase activates the spindle checkpoint by creating unattached kinetochores. Nat Cell Biol 8: 78-83.

Santaguida S, Tighe A, D'Alise AM, Taylor SS, Musacchio A. 2010. Dissecting the role of MPS1 in chromosome biorientation and the spindle checkpoint through the small molecule inhibitor reversine. I Cell Biol 190: 73-87.

Santaguida S, Vernieri C, Villa F, Ciliberto A, Musacchio A. 2011. Evidence that Aurora $\mathrm{B}$ is implicated in spindle checkpoint signalling independently of error correction. EMBO I 30: 1508-1519.

Saurin AT, van der Waal MS, Medema RH, Lens SM, Kops GJ. 2011. Aurora B potentiates Mps1 activation to ensure rapid checkpoint establishment at the onset of mitosis. Nat Commun 2: 316. doi: 10.1038/ncomms1319.

Screpanti E, De Antoni A, Alushin GM, Petrovic A, Melis T, Nogales E, Musacchio A. 2011. Direct binding of Cenp-C to the Mis12 complex joins the inner and outer kinetochore. Curr Biol 21: 391-398.

Stern BM, Murray AW. 2001. Lack of tension at kinetochores activates the spindle checkpoint in budding yeast. Curr Biol 11: 1462-1467.

Tanaka TU, Rachidi N, Janke C, Pereira G, Galova M, Schiebel E, Stark MJ, Nasmyth K. 2002. Evidence that the Ipl1-Sli15 (Aurora kinaseINCENP) complex promotes chromosome bi-orientation by altering kinetochore-spindle pole connections. Cell 108: 317-329.

Taylor SS, Ha E, McKeon F. 1998. The human homologue of Bub3 is required for kinetochore localization of Bub1 and a Mad3/Bub1-related protein kinase. J Cell Biol 142: 1-11.

Tong AH, Evangelista $\mathrm{M}$, Parsons AB, Xu H, Bader GD, Page N, Robinson M, Raghibizadeh S, Hogue CW, Bussey H, et al. 2001. Systematic genetic analysis with ordered arrays of yeast deletion mutants. Science 294: 2364-2368.

Waters JC, Chen RH, Murray AW, Salmon ED. 1998. Localization of Mad2 to kinetochores depends on microtubule attachment, not tension. J Cell Biol 141: 1181-1191.

Westermann S, Cheeseman IM, Anderson S, Yates JR 3rd, Drubin DG, Barnes G. 2003. Architecture of the budding yeast kinetochore reveals a conserved molecular core. J Cell Biol 163: 215-222.

Westhorpe FG, Diez MA, Gurden MD, Tighe A, Taylor SS. 2010. Reevaluating the role of Taol in the spindle checkpoint. Chromosoma 119: 371-379.

Yellman CM, Burke DJ. 2004. Assaying the spindle checkpoint in the budding yeast Saccharomyces cerevisiae. Methods Mol Biol 280: 275290. 


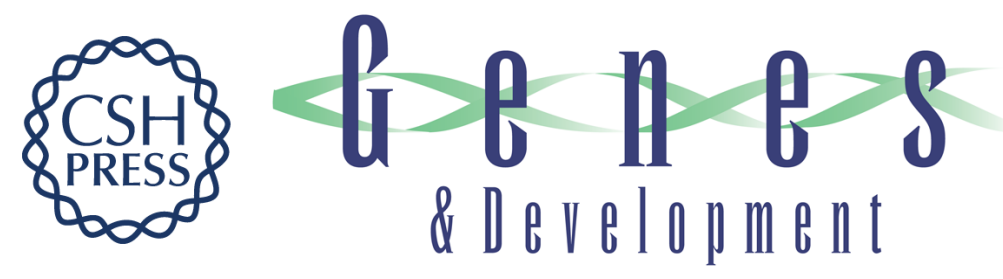

\section{A conserved role for COMA/CENP-H///N kinetochore proteins in the spindle checkpoint}

Daniel R. Matson, Pinar B. Demirel, P. Todd Stukenberg, et al.

Genes Dev. 2012, 26:

Access the most recent version at doi:10.1101/gad.184184.111

\section{Supplemental http://genesdev.cshlp.org/content/suppl/2012/03/16/26.6.542.DC1 Material}

References This article cites 38 articles, 14 of which can be accessed free at: http://genesdev.cshlp.org/content/26/6/542.full.html\#ref-list-1

\section{License}

Email Alerting

Receive free email alerts when new articles cite this article - sign up in the box at the top Service 